\title{
Early diagenetic quartz formation at a deep iron oxidation front in the Eastern Equatorial Pacific - a modern analogue for banded iron/chert formations?
}

\author{
Patrick Meister $^{\mathrm{a}, \mathrm{b} *}$, Bernhard Chapligin ${ }^{\mathrm{c}}$, Aude Picard $^{\mathrm{b}, \mathrm{d}, \mathrm{e}, \mathrm{f}}$, Hanno Meyer ${ }^{\mathrm{c}}$, Cornelius \\ Fischer ${ }^{\mathrm{f}, \mathrm{g}, \mathrm{h}}$, Daniel Rettenwander, Georg Amthauer, ${ }^{\mathrm{i}}$, Christoph Vogt ${ }^{\mathrm{g}}$ and Ivano W. Aiello ${ }^{\mathrm{j}}$

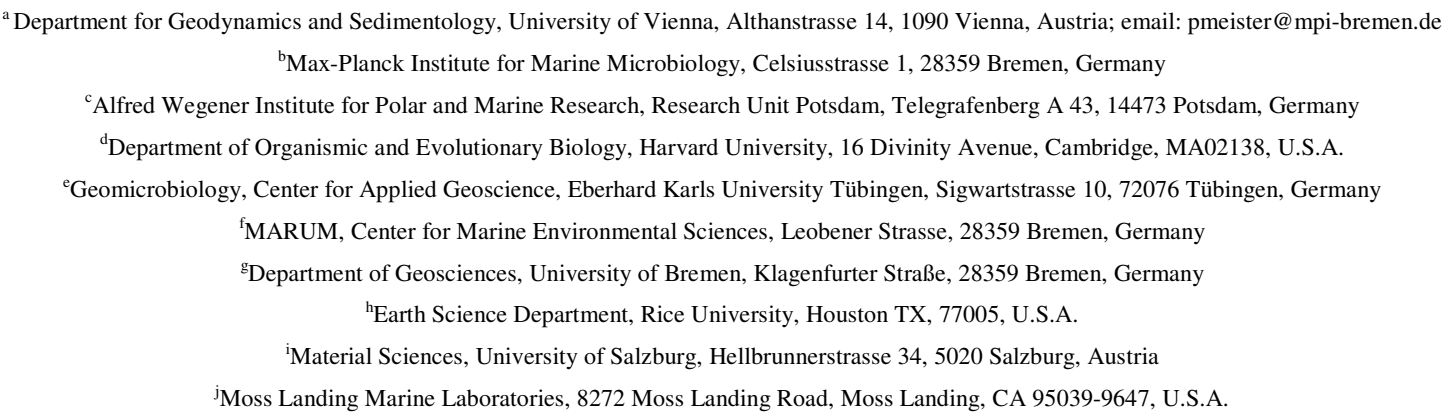

\begin{abstract}
The mechanisms of early diagenetic quartz formation under low-temperature conditions are still poorly understood. In this study we investigated lithified cherts consisting of microcrystalline quartz recovered near the base of a $420 \mathrm{~m}$ thick Miocene-Holocene sequence of nannofossil and diatom ooze at a drill site in the Eastern Equatorial Pacific (Ocean Drilling Program Site 1226). Precipitation seems still ongoing based on a sharp depletion in dissolved silica at the depth of the cherts. Also, palaeo-temperatures reconstructed from $\delta^{18} \mathrm{O}$ values in the cherts are in the range of adjacent porewater temperatures. Opal-A dissolution appears to control silica concentration throughout the sequence, while the solution remains oversaturated with respect to quartz.However, at the depth of the sharp depletion in dissolved silica quartz is still saturated while the more soluble silica phases are strongly undersaturated. Hence, precipitation of quartzwas initiated by some auxiliary process.

A process, previously observed to assist in thenucleation of quartz is adsorption of silica on freshly precipitated ironoxides. Indeed, a deep iron oxidation front is present at $400 \mathrm{~m}$ below seafloor, which is caused by upward diffusing nitrate from an oxic seawater aquifer in the underlying oceanic crust. Sequential iron extraction showed a higher content of the adsorbed iron hydroxide fraction in the chert than in the adjacent nannofossil and diatom ooze. X-ray absorption near-edge structure (XANES) spectroscopy revealed that iron in the cherts predominantly occurs in illite and amorphous iron oxide, whereas iron in the nannofossil and
\end{abstract}


diatom ooze occurs mainly in smectite. Mössbauer spectroscopy also indicated illite that is to 97\%oxidized.

Two possible mechanisms may be operative during early diagenetic chert formation at iron oxidation fronts: (1) silica precipitation is catalysed by adsorption to freshly precipitated iron oxide surfaces, and (2) porewater silica concentration is locally decreased below opal-A and opal-CT saturation allowing for precipitation of the thermodynamically more stable phase: quartz. This mechanism of chert formation at the iron oxidation front in suboxic zones may explain why early-diagenetic microcrystalline chert only occurs sporadically in modern marine sediments. It also may serve as a modern analogue for the deposition of much more abundant banded iron/chert formations at the time of the great oxidation event around $2.4 \mathrm{Ga}$ B.P., which was probably the largest iron oxidation front in Earth history.

\section{Download the complete manuscript:}

http://www.sciencedirect.com/science/article/pii/S0016703714002142 